\title{
Temporal partitioning in an assemblage of insect defoliators feeding on oak on a Mediterranean mountain
}

\author{
MARIA KALAPANIDA ${ }^{1}$ and PANOS V. PETRAKIS ${ }^{2 *}$ \\ ${ }^{1}$ National Agricultural Research Foundation, Forest Research Inst., 57006 Vassilika, Thessaloniki, Greece \\ ${ }^{2}$ National Agricultural Research Foundation, Institute for Mediterranean Forest Ecosystem Research, Laboratory of Entomology, \\ Terma Alkmanos, 11528 Ilissia, Athens, Greece
}

\begin{abstract}
Key words. Quercus, Lepidoptera, Coleoptera, Hymenoptera, oak defoliators, phenology, species coexistence, niche overlap, zoogeographical categories, feeding specialization, Mt Holomontas Chalkidiki Greece
\end{abstract}

\begin{abstract}
Insects feeding on the foliage of oak were studied on a mountain where species of Mediterranean deciduous and evergreen oak coexist. There were 58 insect species (54 Lepidoptera, 1 Coleopteran and 3 Hymenoptera) belonging to twenty families in the assemblage feeding on eight species of Quercus, two of which are introduced from nearby regions. The overlap in occurrence in time and of feeding niches of the insects feeding on the foliage of the different species of oak was determined using the: (a) PooleRathcke method, which tests phenological overlap and (b) Petraitis method, which tests niche overlap. This indicated that insect families partition seasonal time in a random and the entire assemblage in a regular way. All groups of insects partitioned season randomly except for the pairs of monophagous-oligophagous and Palearctic-Eurosiberian species, which partition season regularly. Oak folivorous insects correctly perceive the three subgenera of oaks with the exception of the planted Q. robur pedunculiflora. The folivorous insects recorded on the Mediterranean evergreen oaks (subgenus Sclerophyllodrys) differ from those on the other two subgenera (Quercus and Cerris) and co-occurring deciduous trees. The hypothesis of complete general overlap is rejected for groups based on feeding specialization, zoogeographical categories and taxonomic families. The same was the case when the entire insect assemblage was considered. The percentage of specific niche overlap of the folivorous insects is low and greatest among the monophagous species (13.8\%) and those with a Mediterranean distribution (15.4\%). Voltinism is not very important for this assemblage and only seven species are bivoltine of which four fed on a different species of oak in the second generation. The overall conclusion is that the co-occurrence in space of these species is possible because they occur regularly at different times during the season whereas that of insect groups based on zoogeographical, taxonomic or feeding specialization are randomly dispersed in time.
\end{abstract}

\section{INTRODUCTION}

The guild of oak leaf feeders is a good system for determining the mechanisms that enable different species to coexist. The usual approach to the problem of species coexistence is to assume resource partitioning (Schoener, 1986) or a multitude of effects on the niche [such as niche compression (Schoener, 1974b)]. This enables several species to share the same resource even though they use a single though widespread trophic substrate such as oak foliage. The leaves of oaks are consumed by several mammalian and many invertebrate herbivores (Patocka, 1980; Gaus, 1982; Cornell, 1985; Karban, 1985; Marquis \& Phelan, 1994). Among the later group, insects prevail and consume the foliage of oak trees in several ways, such as chewing, mining, sucking or gall forming. A certain feeding type may locally or temporally dominate but as a rule the most serious for the plant are those insects that consume the photosynthetic tissue by chewing, which can result in severe defoliation. For some authors defoliation by insects is among the most important biotic factors contributing to the decline of oak in Central Europe (Fürher, 1998).

Resource partitioning traditionally involves two, or at most three, axes along which species differ in their exploitation of a resource and this difference can be reflected in their population dynamics. As a result the life cycles of foliage consumers are synchronized with leafflushing and the peak food-quality of the foliage (Niemelä \& Haukioja, 1982; Alonso \& Herrera, 2000).

A search of the recent literature showed that time is either indirectly recorded or if not, usually invoked in explanations of species coexistence and abundance patterns. In studies on phytophagous insects time is indirectly recorded in the seasonality of abiotic factors (e.g. Schoener, 1974a, 1986; Niemelä \& Haukioja, 1982; Van Asch \& Visser, 2007) or the quality of the feeding substrate (e.g. Coley et al., 1985; contra Altermatt, 2010), which includes the chemical defenses of leaves (Feeny, 1970). In addition, the exact timing is potentially important for many physiological mechanisms by which insect consumers of plants synchronize their development with that of their host plant (Mopper, 2005; Van Asch \& Visser, 2007). Only recently has time been considered as a resource axis because it permits the interaction of temporally non-overlapping species by incorporating the dynamics of the consumed resources (Loreau, 1992). Insects are consumers with a generation time close to that of their food resource (Mopper, 2005; Alonso \& Herrera, 2000).

\footnotetext{
* Corresponding author; e-mail: pvpetrakis@fria.gr
} 
TABLE 1. The species of oak found on Mt Cholomontas and used in this study. The subgenus and the taxonomic status are based on Flora Europaea (Schwarz, 1964) and personal observations (KM and PVP). Plant cover classes are expressed in terms of the Domin scale (Van der Maarel, 1979).

\begin{tabular}{lcccc}
\hline Oak species $($ Quercus $)$ & Subgenus & Status & Plant cover classes & Bud burst midpoint \\
\hline frainetto Ten. & Quercus & native & 8 & late March \\
dalechampii Ten. & Quercus & native & 2 & late March \\
pubescens Willd. & Quercus & native & 4 & early - mid April \\
ilex L. & Sclerophyllodrys & native & 2 & late April - late May \\
coccifera L. & Sclerophyllodrys & native & 3 & mid April - late May \\
trojana Webb & Cerris & planted ${ }^{1}$ & 1 & mid March \\
macrolepis Kotschy & Cerris & native & 2 & mid March \\
robur L. subsp. pedunculiflora (C. Koch) & Quercus & planted ${ }^{1}$ & 2 & late March \\
\hline
\end{tabular}

${ }^{1}$ As the seeds of these plants were collected from neighbouring areas of oak forest it is characterized as semi natural.

For these consumers time is expected to be a major niche dimension and is important in the segregation of species by decreasing competition even when they use the same feeding substrate. In addition to the timing and duration of the feeding stage of oak insects on the axis of seasonal time, voltinism is a life-cycle feature that permits the exploitation of foliage resources, possibly by tracking the chemical defenses of host plants and offers an additional escape from competition and natural enemies (Cizek et al., 2006).

The insects that consume oak leaves constitute a taxonomically compact and ideal insect-plant system for testing several hypotheses of species coexistence and maintenance of biodiversity (Southwood et al., 2004). We established four stands in an oak forest on Mt Holomontas (Chalkidiki, Greece) in order to study such a system (i) in a small geographical area (ii) both on native and introduced species of oak in a (iii) deciduousevergreen continuum (Ne'eman, 1993) of oaks of (iv) different range types, (v) on eight species of three subgenera of Quercus.

In this paper we determine whether: [1] Larvae of the different folivorous insects on the oaks are temporally segregated within the seasonal window in accordance with the seasonality of oak physiology. [2] Insects that are generalist feeders with broad geographical ranges and are taxonomically related (e.g. confamilial) have little or no temporal overlap in their exploitation of a common resource (Schoener, 1974a; Southwood \& Kennedy, 1983). Germane to this is the opinion that there is a trend in insects towards monophagy as a strategy for reducing overlap (Jolivet, 1998). [3] When the utilization of the food resources of a particular species of oak tree is considered, the estimated feeding niches of the folivorous insects overlap less than they do when only the phenologies of the feeding stages are considered. [4] There is any difference in the folivorous insect assemblages on native and introduced oaks in terms of species richness, feeding specialization, or zoogeographical category of origin?

\section{METHODS}

\section{Study site}

The study site is in an oak-forest on Mount Holomontas $\left(23^{\circ} 30^{\prime} \mathrm{E}, 40^{\circ} 25^{\prime} \mathrm{N}\right)$ Chalkidiki, Greece. It is a natural forest that was partially coppiced 60 years ago and is dominated by $Q$. frainetto and $Q$. pubescens at high and $Q$. ilex and $Q$. coccifera at low altitudes. In all plots oaks (eight species in all, Table 1) were dominant. Four altitudes were selected, which were representative of the variability in the area and ground vegetation: very low $(<100 \mathrm{~m})$, low $(100-250 \mathrm{~m})$, medium $(250-550 \mathrm{~m})$ and high $(>850 \mathrm{~m})$. At each site four two hectare rectangular plots that included all the oak species were studied. The plot with the highest oak cover was considered to be the most representative (base plot). Collectively other tree/shrub species accounted for less than 7 percent of the cover.

At each site a nearby sheltered place was used for rearing (in $21 \times 7 \times 5 \mathrm{~cm}$ boxes) and phenological observations on the insects. One or two small branches from various exposures and different heights in the canopy of each oak tree were cut on each sampling session and used as a substrate for rearing the insects. These observations acted as a guide for insect sampling and provided important phenological details about the insects.

Plant cover was measured using the point quadrat method (Aber, 1979) and cover values expressed in terms of the Domin scale (van der Maarel, 1979).

\section{Collection and identification of insects}

Insects were collected weekly from March until November, and monthly in December and February (1997-1998). These years were selected because the insects were then more abundant on oaks. Samples of insects were collected from all the understory plants and nearest non oak deciduous trees to the oaks that were sampled at monthly intervals.

In the base plot at each site, up to five branches (mean 3.7) at $0-1 \mathrm{~m}, 1-2.5 \mathrm{~m}, 2.5-4 \mathrm{~m}$ and above $4 \mathrm{~m}$ in the crown of each species of oak, which corresponds to samples from three randomly selected individual trees (Yela \& Herrera, 1993), were sampled for caterpillars by beating and hand collecting (Harris et al., 1972). The scheme was done according to the equation 4 plots/site X 3 trees/plot X 4 (crown heights)/tree X 3.7 branches/(crown height) $\mathrm{X}$ stands $\approx 710$ branches. Branches were covered with cloth sleeves at the time of examination to collect the caterpillars that were dislodged from the foliage; at the end of the sampling session the number of caterpillars in the sleeves were recorded and then returned to the foliage. Immature stages were noted and in a few cases those species new to the study or unknown were removed for further examination or rearing in the nearby sheltered place. The branches were individually beaten for $10 \mathrm{~s}$ by using a modified handheld vibrating apparatus (Campagnola - MAIBO, Bologna, Italy; 12 Volts, 2 beats/s). The time spent beating and number of branches beaten were the same at all sampling sessions throughout this study. The sampled branches were tagged and not re-sampled in the same month. 
TABLE 2. List of the types of insects recorded in this study at sites on Mt. Cholomontas. [a] Explanation of zoogeographical categories (Josifov, 1986). [b] Feeding specialization of the phytophagous insects recorded in this study based on Jolivet (1998).

[a]

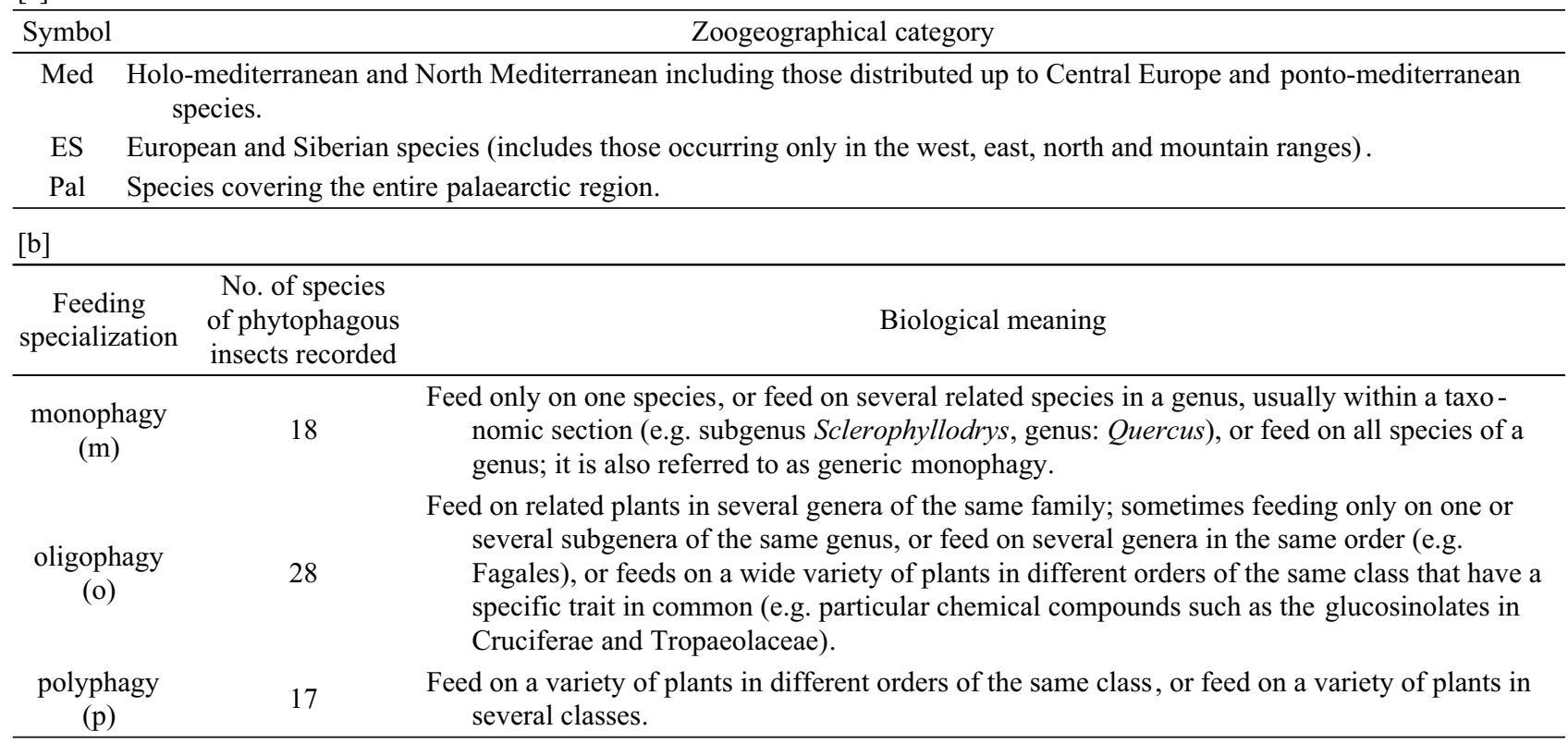

In the three remaining plots at each site, considered as replicates, sampling was similar except for the rearing of insects. For the comparisons of the insects on the different species of oak the numbers of insects counted at each sampling session were weighted by the cover value of each oak species and expressed as insects occurring in a 2 ha plot at each site.

Two trees of each species of oak at each site, were once a year (April, May or October) sampled using chemical knockdown, which involves mist-blowing (Golden Eagle, CA) of the foliage (Southwood et al., 1985; Ozanne, 2005) with cypermethrin (Protecta, Athens, Greece) to ensure that all species of insect were sampled. For the same purpose understory deciduous tree/shrub genera were examined for fallen caterpillars that were not collected by beating branches.

\section{Characterization of insects}

Three categories of feeding specialization were defined according to the scheme of Jolivet (1998), which is similar to that used for oak insects by Southwood et al. (2004) (Table 2). The subcategories of feeding specialization were not considered. They were collapsed into the three major classes to increase the power of the associated statistical tests.

Zoogeographical categories were derived from a list of East Mediterranean insects (Josifov, 1986) and collapsed into three i.e. $\mathrm{Pal}=$ Palearctic distribution, $\mathrm{ES}=$ distributed in the Eurosiberian region, and Med = distributed around the Mediterranean - to increase the power of the subsequent statistical tests. Each insect species was assigned to a category according to its geographical distribution derived from Schwenke (1978, and references therein) (additional entries are listed in Appendix S1). The same sources were used to determine the host range of insects along with our own observations.

Voucher specimens are deposited in the insect collections of the Forest Research Institutes in Athens and Thessaloniki.

\section{Measurement and testing of the segregation in time of the insects}

Since it is expected that the different species of insect will be present at different times during the course of the season in order to minimize inter-specific competition then there should be little overlap in the time of occurrence of the larvae of the different species on each species of oak. To determine whether this is the case the Poole-Rathcke model (Poole \& Rathcke, 1979; Rathcke, 1984) was used (Appendix S3). This method constructs the null hypothesis $H_{0}$ that larval periods are independent and random events. If time is conceived as one dimensional niche space then their boundaries are random points, as in the broken stick model (= random niche-boundary hypothesis) of MacArthur (Giller, 1984; Fattorini, 2005).

The starting date for the larval periods off all species is bud burst, which begins on the $59^{\text {th }}$ day from the start of the year, which occurs within \pm 7 days of the first egg hatching.

To compare the phenologies of two insect groups we used the statistic $F_{s}=\mathrm{Dr}_{1} / \mathrm{Dr}_{2}$ (Rabinowitz et al., 1981). This $F$ statistic has $k_{1}$ and $k_{2}$ degrees of freedom, which correspond to the numbers of species of insects in the two groups. The grouping criteria were moth families, feeding specialization and zoogeographical categories. The phenologies in each of these groups were compared to those of the entire guild of insects eating oak foliage. In this way, we tested two null hypotheses. The first $\left(H_{01}\right)$ states that the dispersion of insect species within families is not significantly different from random and the second $\left(\mathrm{H}_{02}\right)$ that the dispersion in both tested groups are not significantly different.

\section{Measurement of niche overlap}

As the Poole-Rathcke model uses only phenological data we used measures of niche overlap in order to introduce the effect of population density on the exploitation of resources. Niche "general overlap" is measured as a complement of time segregation in insects by including quantification into the interaction between species. The chosen measures were the Petraitis' (1979, $1985)$ "specific" $(S O)$ and "general overlap" $(G O)$, which were statistically tested using the statistic $V$ that has a $\chi^{2}$-distribution with $(s-1) \cdot(r-1)$ degrees of freedom, where $s$ represents the number of insect species and $r$ the number of resource classes. The $S O_{i j}$ value represents the likelihood that the utilization curve of species $i$ is derived from the curve of species $j$; because of differences in utilization of resources by species $i$ and $j$ the 
reverse is not in general true and the derived $S O$ values are as a rule asymmetrical, that is $S O_{i j} \neq S O_{i l}$.

The same holds for all species in the assemblage and is defined as the probability that the utilization curves of all species are drawn from a common curve. Resource classes were considered to be the species of oak on which the insects occurred.

The values of "specific overlap" were used in the formation of feeding clusters. The clustering method employed was the Ward clustering minimum (Orloci, 1979) variance algorithm operated on the "specific overlap" matrix of all individual folivorous insects. The estimate of the level of cluster recognition was obtained as follows: [1] The recognition of the first feeding cluster was done by considering the longest stem in the dendrogram starting from the root, which according to McCune et al. (2002) characterizes a natural group. The transverse line drawn from this node defines six other clusters. [2] This level of cluster recognition is supported by employing either the validity index plot of pseudo $F$ or pseudo $T$-square functions (Wilkinson, 2007). [3] The level of six clusters is also indicated
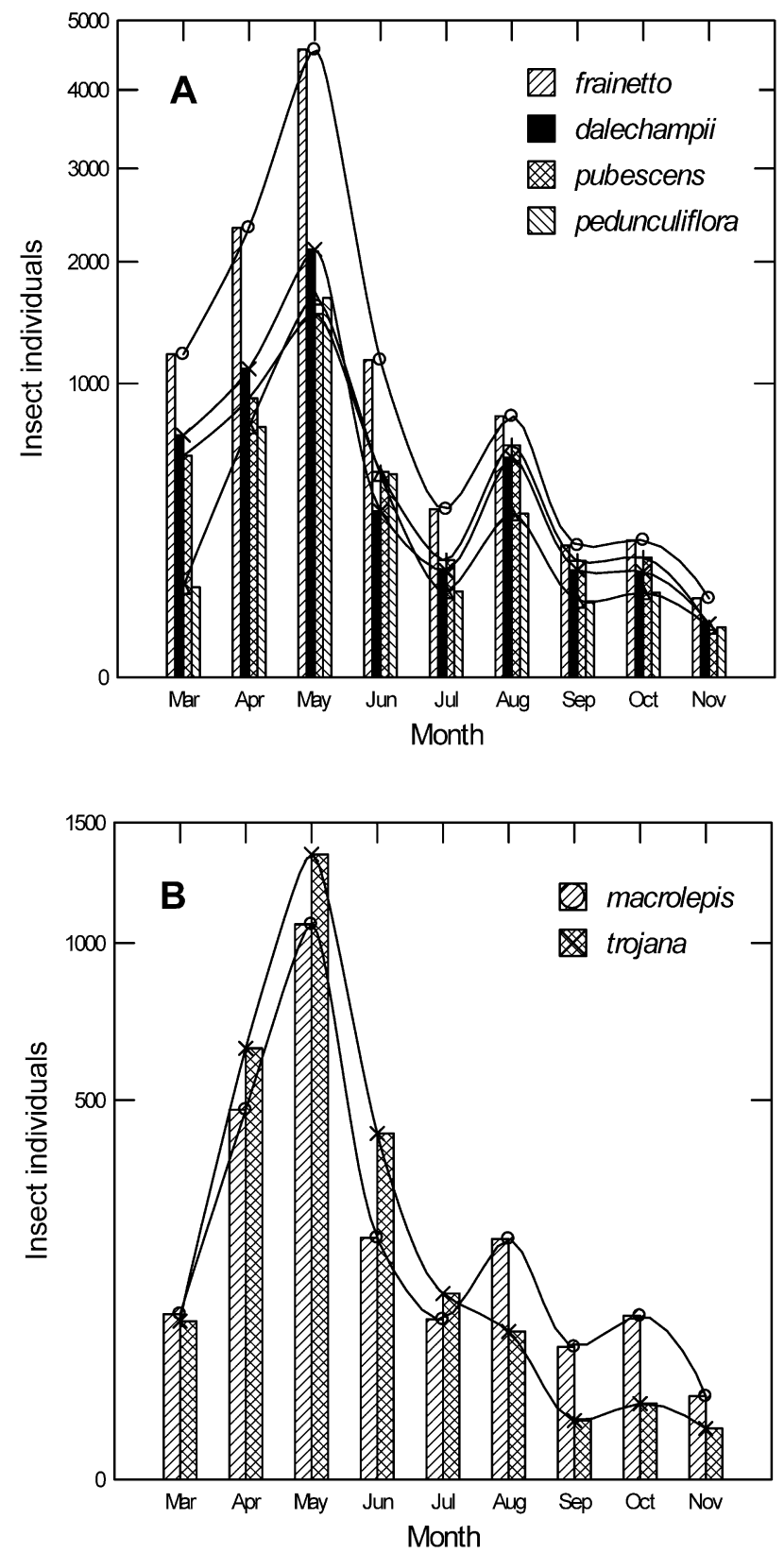

by clues procedure as it maximizes the Silhouette index (Chang et al., 2010). In this study all three methods of cluster recognition indicated the same number of clusters.

Within each cluster the randomness of insect larval phenologies, measured by the mean of the start and end date was tested using the Wald-Wolfowitz runs test (Wilkinson, 2007).

The shift to another cluster of the second generation of an insect was measured as the number of nodes met when moving from one cluster to another. Statistical analyses were performed using SYSTAT 12 (Wilkinson, 2007), R (R Development Core Team, 2008) and the packages clues (Chang et al., 2010), vegan (Oksanen et al., 2008) and PAST (Hammer \& Harper, 2006).

\section{RESULTS}

In this study all the species of Quercus (Table 1) were locally abundant. The foliage of these oak trees was eaten by 58 species of insect belonging to three orders and twenty families, mostly Lepidoptera, Table 2 and Table S2 (both panels, supplementary material). Seven species

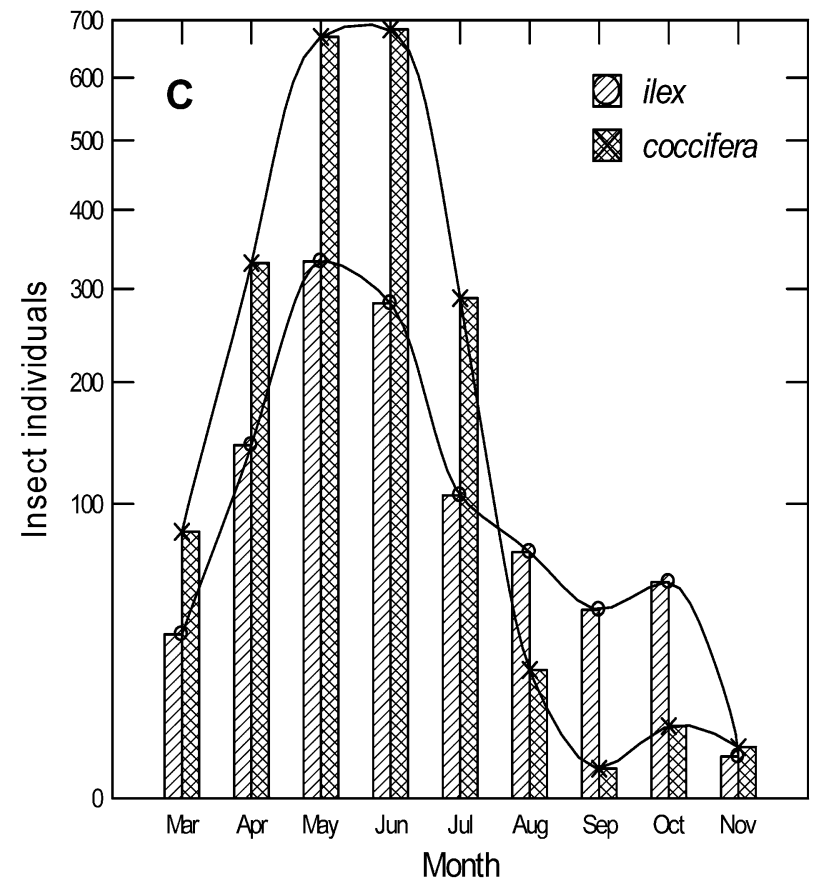

Fig. 1. Abundance of foliage chewing insects recorded each month on each species of Quercus. In order to show low abundances square root data are presented. The tops of the bars are connected by a smooth curve (spline interpolation) to reveal seasonal trends in insect abundances. The three plots correspond to the three subgenera of the genus: A - Quercus, B - Cerris and C-Sclerophyllodrys. 


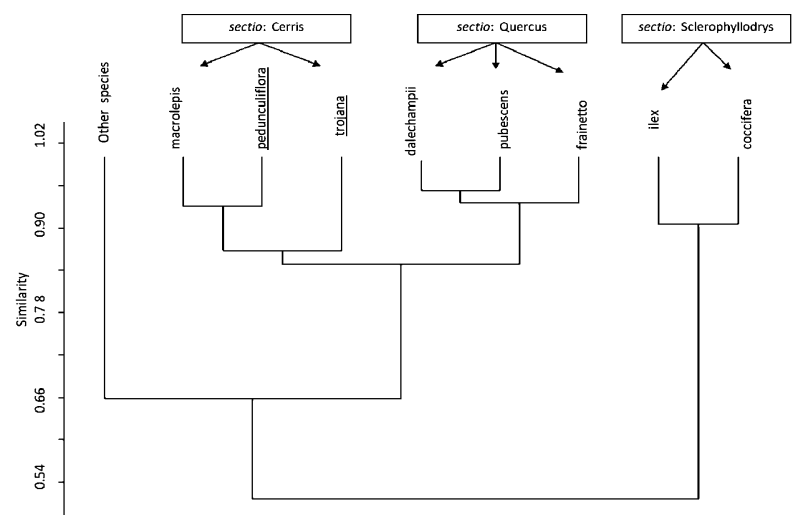

Fig. 2. The different species of oak classified on the basis of the presence/absence of species of chewing insects feeding on their foliage. Insects occurring in all months were used. The clustering method used is UPGMA of Ochiai binary similarity coefficients (Hammer \& Harper, 2006). The subgenera (sectio) of Quercus are in the boxes above the clustering nodes. Introduced oaks ( $Q$. robur subsp. pedunculiflora and $Q$. trojana) are underlined. Only $Q$. robur pedunculiflora is clustered in another subgenus close to Q. macrolepis. The label "Other species" denotes all co-occurring deciduous tree/shrub species.

are bivoltine and another may have had a second generation.

\section{The seasonal pattern of leaf chewers on oak species}

The abundances of the different species leaf chewers on the different species of one genus and two subgenera of oak are shown in Fig. 1. As a rule there are three peaks in abundance peaks except on species of the subgenus Sclerophyllodrys on which the second and third peaks are not prominent or do not exist. On $Q$. trojana in the subgenus Cerris there is no August peak. The same peak is evidenced as a swelling of the abundance curve on $Q$. ilex. On Sclerophyllodrys there is a prolongation of the season with the peak in May extending to June.

As expected, insect abundance is higher on oaks with a higher coverage. However, the Pearson product-moment correlation coefficients of insect monthly abundances with the coverage of all eight oak species are moderate $\left(\mathrm{r}_{1}\right.$ $=0.639, \mathrm{r}_{2}=0.585, \mathrm{r}_{3}=0.331$ for the three main peaks). This is partly due to the crossing of the $Q$. pubescens abundance curve with other species of the same section, and the crossings in the other two subgenera (Fig. 1).

The tree diagram in Fig. 2 indicates that the insects correctly perceive all the species of the genus and two subgenera of oaks with the exception of the planted $Q$. robur pedunculiflora. This diagram was constructed on the basis of presence of insects (UPGMA of Ochiai distances) and shows that the species of the subgenus Scle-

TABLE 3. Presentation of the results obtained when the Poole-Rathcke method was used to segregate the moths in time. The null hypothesis $\left(H_{01}\right)$ states that the dispersion $(D r)$ is not significantly different from random and the second null hypothesis $\left(H_{02}\right)$ that the two dispersions are not significantly different. Panel [a] is for insect families, [b] is for feeding specialization and [c] for biogeographical categories.

\begin{tabular}{|c|c|c|c|c|c|}
\hline \multicolumn{6}{|l|}{ [a] } \\
\hline Family & $\begin{array}{c}k \\
\text { No. of species }\end{array}$ & $\begin{array}{c}P \text { Observed } \\
\text { variance }(\times 1000)\end{array}$ & $\begin{array}{c}E(P) \text { Expected } \\
\text { variance }(\times 1000)\end{array}$ & $\begin{array}{c}D r=P / E(P) \\
\text { Dispersion ratio }\end{array}$ & $\begin{array}{l}\text { Random dispersion } \\
\text { (significance of } H_{01} \text { ) }\end{array}$ \\
\hline Geometridae & 11 & 3 & 70 & 0.036 & ns (random) \\
\hline Noctuidae & 10 & 19 & 76 & 0.254 & ns (random) \\
\hline Tortricidae & 10 & 41 & 76 & 0.538 & ns (random) \\
\hline Insect assemblage & 63 & 63 & 0.015 & 4.161 & $* * *$ \\
\hline \multicolumn{6}{|l|}{ [b] } \\
\hline $\begin{array}{l}\text { Feeding } \\
\text { specialization }\end{array}$ & $\begin{array}{c}k \\
\text { No. of species }{ }^{1}\end{array}$ & $\begin{array}{c}P \text { Observed } \\
\text { variance }(\times 1000)\end{array}$ & $\begin{array}{c}E(P) \text { Expected } \\
\text { variance }(\times 1000)\end{array}$ & $\begin{array}{c}D r=P / E(P) \\
\text { Dispersion ratio }\end{array}$ & $\begin{array}{l}\text { Random dispersion } \\
\text { (significance of } H_{01} \text { ) }\end{array}$ \\
\hline monophagous & 18 & 0.42 & 2.74 & 0.153 & ns \\
\hline oligophagous & 28 & 1.11 & 820.28 & 0.001 & ns \\
\hline polyphagous & 17 & 0.52 & 2.76 & 0.188 & ns \\
\hline \multicolumn{2}{|c|}{ Feeding specialization compared } & \multicolumn{2}{|c|}{$F s=D r_{1} / D r_{2}$} & \multicolumn{2}{|c|}{ Same distribution (significance of the $H_{02}$ ) } \\
\hline \multicolumn{2}{|c|}{ monophagous - oligophagous } & \multicolumn{2}{|c|}{113.3} & \multicolumn{2}{|c|}{$* * *$} \\
\hline \multicolumn{2}{|c|}{ monophagous - polyphagous } & \multicolumn{2}{|c|}{0.814} & \multicolumn{2}{|c|}{ ns } \\
\hline oligophagous - pol & agous & \multicolumn{2}{|c|}{0.007} & \multicolumn{2}{|c|}{ ns } \\
\hline \multicolumn{6}{|l|}{ [c] } \\
\hline \multicolumn{2}{|c|}{ Zoogeographical categories } & $\begin{array}{c}k \\
\text { No. of species }\end{array}$ & $\begin{array}{c}D r=P / E(P) \\
\text { Dispersion ratio }\end{array}$ & \multicolumn{2}{|c|}{$\begin{array}{l}\text { Random dispersion } \\
\text { (significance of } H_{0 l} \text { ) }\end{array}$} \\
\hline \multicolumn{2}{|l|}{ Mediterranean } & 21 & 0.315 & \multicolumn{2}{|c|}{ ns (random) } \\
\hline \multicolumn{2}{|l|}{ Eurosiberian } & 24 & 0.144 & \multicolumn{2}{|c|}{ ns (random) } \\
\hline \multicolumn{2}{|l|}{ Palearctic } & 13 & 0.370 & \multicolumn{2}{|c|}{ ns (random) } \\
\hline \multicolumn{2}{|c|}{ Zoogeographical categories compared } & \multicolumn{2}{|c|}{$F s=D r_{1} / D r_{2}$} & \multicolumn{2}{|c|}{ Same distribution (significance of the $H_{02}$} \\
\hline \multicolumn{2}{|c|}{ Palearctic - Eurosiberian } & \multicolumn{2}{|c|}{2.569} & \multicolumn{2}{|c|}{$*$} \\
\hline \multicolumn{2}{|c|}{ Palearctic-Mediterranean } & \multicolumn{2}{|c|}{1.176} & \multicolumn{2}{|c|}{ ns (random) } \\
\hline \multicolumn{2}{|c|}{ Eurosiberian - Mediterranean } & \multicolumn{2}{|c|}{0.459} & \multicolumn{2}{|c|}{ ns (random) } \\
\hline
\end{tabular}

${ }^{1}$ When there is more than one generation the second generation is treated as a separate species; * corresponds to a probability of $0.05, * *$ to 0.01 and $* * *$ to $<0.001$. 
TABLE 4. Specific niche overlap ( $S O$ ) of oak foliage eating insects within the various categories of feeding specialization and zoogeographical categories, which are grouped into two large categories of distribution.

\begin{tabular}{ccccc}
\hline & No. of species & No. of significant $S O \mathrm{~s}^{1}$ & $\%$ of all $S O \mathrm{~s}$ & $\%$ asymmetrical significant $S O \mathrm{~s}$ \\
\hline Feeding specialization & & & & \\
\hline $\mathrm{m}$ & 16 & 33 & $13.8 \%$ & $6.1 \%$ \\
$\mathrm{o}$ & 24 & 11 & $2.0 \%$ & - \\
$\mathrm{p}$ & 21 & 4 & $0.3 \%$ & $27.3 \%$ \\
\hline Zoogeographical categories & & & $0.6 \%$ & $25.0 \%$ \\
\hline ES + Pal & $24+21$ & 12 & $15.4 \%$ & $8.3 \%$ \\
Med & 13 & 24 & & \\
\hline
\end{tabular}

${ }^{1}$ Overlaps between species are significant.

rophyllodrys differ from those of the other genus and subgenus of oak and co-occurring trees and shrubs.

\section{Segregation in time of the insects}

The entire assemblage of folivorous insects exploits time in a non-random way despite the fact that species within individual insect families partition time randomly (Table 3a). Seven families are represented in the area by only one species and their observed variance $(P)$ cannot be calculated using the Poole-Ratchke model. However, only three families were represented by enough species for the statistical tests to have sufficient power (Table 3a). Nevertheless, even though the species of the three families with enough species are randomly distributed in the season, the assemblage of all the insect families exploits time in a non random way.

Feeding specialization is a direct measure of an insect's affiliation with its host plant(s). In this study the occurrence in time of insects with all three types of specialization are randomly distributed throughout the season. However for the entire assemblage the distribution is non random (Table 3b).

In terms of the three zoogeographical categories (Table 3c) all three geographical distribution groups have random phenologies. The widely distributed insects in the categories (Pal and ES) have statistically different geographical distributions but that of those in category Med are similar to Pal and ES.

\section{Insect niche overlap}

The niches of the folivorous insects on oak only overlap slightly $(G O=0.443)$ with minimum possible value of GOmin $=0.021$ and a sample size free (Ludwig $\&$ Reynolds, 1988) adjusted value of 0.431 . When absolute numbers are considered the overlap does not change substantially $(G O=0.428$ with $G O \min =0.025)$. Since the minimum overlap value is close to zero there is no need to adjust for the number of species in the sample. The "general overlap" is not complete $\left(\chi^{2}=641.92\right.$, d.f. $=$ $480, \mathrm{~ns})$ indicating there is some overlap. Most species pairs have zero overlap and less than $10 \%$ of species pairs have overlap values greater than 0.5 (Table 4).

There is a large number of significant asymmetries in the overlap ( $S O$ ) values for the oligophagous species and those with broad geographical distributions (ES and Pal) (Table 4). In general the number of significant SOs is negatively correlated with the number of asymmetrical overlaps indicating that the feeding and zoogeographical categories are densely packed, that is those with a high $G O$, are also richer in asymmetrical pairs (oligophagous species and ES + Pal in Table 5).

In all the feeding specialization categories (Table 5) the "general overlap" does not change when it is adjusted for the number of species, except in the case of the monophagous insects, where the change is substantially smaller. In this way a gradient of values is created and $G O$ is highly and significantly rank correlated with feeding specialization $\left(r_{\text {rank }}=0.80 ; P<10^{-3}\right)$ when the data in Table 2a, c on feeding specialization is considered. In the zoogeographical categories $G O$ decreases with increase in geographical area $(\mathrm{Pal}>\mathrm{ES}>$ Med, Table 5).

Turning to specific overlaps significances are very rare (Table 4). Among feeding specialists there are no signifi-

TABLE 5. General, adjusted and minimum (GOmin) niche overlap within the various classes of feeding specialization and zoogeographical categories. The hypothesis $H_{0}$ states that the overlap between species is complete.

\begin{tabular}{ccccc}
\hline & General overlap & GOmin & Adjusted general overlap & $H_{0}$ \\
\hline Feeding specialization & & & & \\
\hline $\mathrm{m}$ & 0.545 & 0.090 & 0.500 & rej \\
$\mathrm{o}$ & 0.583 & 0.058 & 0.558 & rej \\
$\mathrm{p}$ & 0.483 & 0.068 & 0.445 & rej \\
\hline Zoogeographical categories & & & 0.458 & rej \\
\hline ES & 0.483 & 0.045 & 0.473 & rej \\
Pal & 0.505 & 0.061 & 0.362 & rej \\
\hline Med & 0.412 & 0.079 & & \\
\hline Ansect assemblage & & & & rej \\
\hline
\end{tabular}




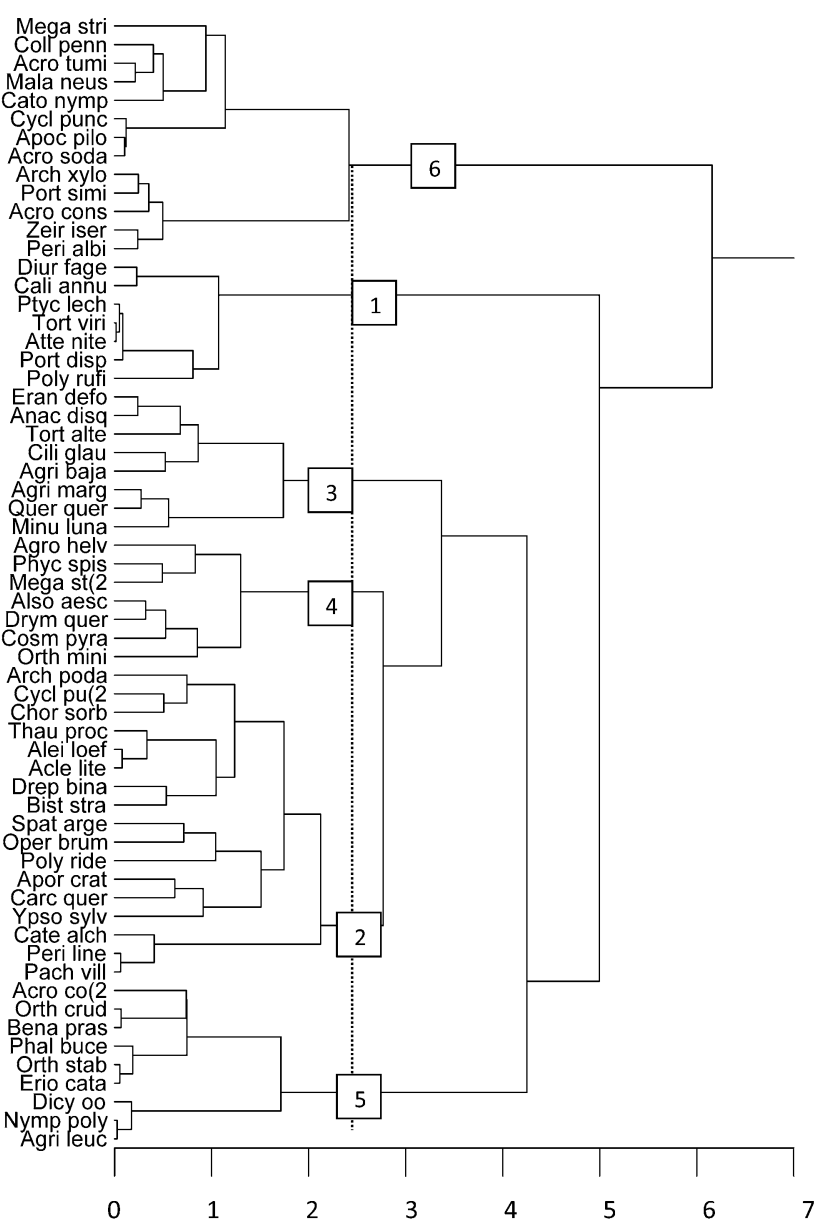

Fig. 3. Dendrogram showing the hierarchical Ward clustering of oak foliage eating species based on their niche specific overlap computed without taking into account time of occurrence during the season. The six designated clusters (see text for details) are marked with Arabic numerals (1..6). All species are denoted with the first four letters of genus and species names. Species "Acro co(2", "Cycl pu(2" and "Mega st(2" correspond to the second generation of $A$. consociella, $C$. punctaria and $M$. strigula on a different species of host tree. The scale at the bottom represents Euclidean distances.

cant complete overlaps while among the sub-specialists (not strictly monophagous or polyphagous) the overlaps are between the species Dicycla oo and Caliroa annulipes (both directions) and Phalera bucephaloides and Periclista albida. Of the oligophagous species feeding on oak foliage only the niches of Tortrix viridana and Zeiraphera isertana completely overlap. Polyphagous insects show the least number of significant unidirectional and no asymmetrical complete overlaps. Among them the most pronounced are the $\mathrm{SO}$ s of Biston strataria, Archips podana and Porthesia similis.

\section{Segregation in time and niche overlap}

Based on the niche specific overlap values and employing the Ward joining algorithm, the insects were assigned to six clusters (Fig. 3). The results of the WaldWolfowitz runs test for the statistical inference on the randomness of larval phenologies within each cluster are
TABLE 6. [a] Insect genera with more than one species are listed. The presence of a species in a cluster is represented by its number in this cluster and row sums represent the number of species in the respective genus. The exception is the second generation of Acrobasis consociella in cluster 5. [b] Insect species with a second generation and their cluster affiliation. If the second generation is affiliated to another cluster then an arrow marks this transition. If not then a filled circle is entered in the respective cluster.

\begin{tabular}{|c|c|c|c|c|c|c|}
\hline \multirow{2}{*}{ Genus } & \multicolumn{6}{|c|}{ Cluster } \\
\hline & 1 & 2 & 3 & 4 & 5 & 6 \\
\hline \multicolumn{7}{|l|}{ [a] } \\
\hline Acrobasis & & & & & 1 & 3 \\
\hline Agriopis & & & 2 & & 1 & \\
\hline Archips & & 1 & & & & 1 \\
\hline Orthosia & & & & 1 & 2 & \\
\hline Periclista & & 1 & & & & 1 \\
\hline Polyploca & 1 & 1 & & & & \\
\hline Porthetria & 1 & & & & & 1 \\
\hline \multicolumn{7}{|l|}{ [b] } \\
\hline A. consociella & & & & & & \\
\hline M. strigula & & & & 4 & & $\bullet$ \\
\hline C. punctaria & & & & & & - \\
\hline D. binaria & 4 & $\bullet$ & & & & \\
\hline A. literana & $\bullet$ & & & & & \\
\hline S. argentina & $\bullet$ & & & & & \\
\hline M. neustria & & & & & & $\bullet$ \\
\hline
\end{tabular}

shown in Table S4 (supplementary material). All clusters are randomly dispersed throughout the season.

Insect genera with more than one species show the following pattern. All species of the same genus are affiliated to two clusters. The genera Agriopis and Orthosia have two species in one cluster and the second generation of $A$. concosiella moves to cluster 5 (Table $5 \mathrm{a}$ ). Four out of seven species that have a second generation (bivoltine) exhibit a shift in feeding cluster (Table 5b). Clusters 1 and 6 include the bivoltine species in which the second generation does not change cluster while the other clusters includes those insects that change cluster in the second generation. It must be noted that clusters 1 and 6 have the longest branches in the dendrogram (Fig. 3). In the same figure the mean distance of the shifts is 6.25 , which is very close to the average distance between all clusters, which is 5.0. The other three species remain in the same cluster probably because they exploit abundant resources.

Bivoltine species with a $S O$ like the other insects of less than 0.165 , which is the mean $S O$ of all insect species (Table 6), are variable in their behaviour in terms of shifting cluster. For example the monophagous species, A. literana, does not show cluster shift while A. consociella with higher than 0.165 mean $S O$, moves in the second generation to another cluster, i.e., 5. In oligophagous insects, $C$. punctaria with a very low mean $S O$ $(0.080)$ exhibits cluster shift while the remaining oligophagous species exhibit variable behaviour. The 
TABLE 7. Niche specific overlap of insect species with a second generation compared with the mean specific overlap of all insects $\left(\overline{S O}_{\text {all }}=1.165\right)$.

\begin{tabular}{|c|c|c|c|c|}
\hline Insect species & Hypothesis tested & $\begin{array}{c}\text { Estimated specific overlap } \\
{[\text { mean } \pm \text { SD }]}\end{array}$ & $t$ - value & $P$ \\
\hline \multicolumn{5}{|c|}{ monophagous, $\overline{S O}_{\text {mono }}=1.194$} \\
\hline Acrobasis consociella & ${\overline{S O}=\overline{S O}_{\text {mono }}}$ & $0.184 \pm 0.300$ & 0.357 & $0.362 \mathrm{NS}$ \\
\hline Acleris literana & $S O=\overline{\overline{S O}}_{\text {mono }}$ & $0.113 \pm 0.188$ & -1.563 & $0.128 \mathrm{NS}$ \\
\hline \multicolumn{5}{|c|}{ oligophagous, $\overline{S O}_{\text {oligo }}=1.190$} \\
\hline Drepana binaria & $S O=\overline{\overline{S O}}_{\text {oligo }}$ & $0.223 \pm 0.165$ & 0.893 & $0.381 \mathrm{NS}$ \\
\hline Cyclophora punctaria & $S O=\overline{\overline{S O}}_{\text {oligo }}$ & $0.080 \pm 0.129$ & -4.775 & $<10^{-4}$ \\
\hline Meganola strigula & $S O=\overline{\overline{S O}}_{\text {oligo }}$ & $0.280 \pm 0.228$ & 2.874 & 0.006 \\
\hline Spatalia argentea & $S O=\overline{\overline{S O}}_{\text {oligo }}$ & $0.183 \pm 0.260$ & 0.493 & $0.624 \mathrm{NS}$ \\
\hline \multicolumn{5}{|c|}{ polyphagous, $\overline{S O}_{p o l y}=0.093$} \\
\hline Malacosoma neustria & $S O<\overline{\overline{S O}}_{p o l y}$ & $0.106 \pm 0.234$ & -1.476 & $0.075 \mathrm{NS}$ \\
\hline
\end{tabular}

NS - not significant.

polyphagous species $M$. Neustria, with a mean $S O$ lower than 0.165 , does not exhibit a cluster shift.

The mean SO of insect feeding specializations decreases with decreasing specialization, with values of $0.194,0.190$ and 0.093 (Table 6). However, this pattern is not shown in the values of general overlap $G O$ (Table 4) due to the $G O$ values of the oligophagous insects.

\section{DISCUSSION}

The number of species recorded in this study is similar to that recorded for other Greek oak forests (Kailidis, 1986) and comparable to that recorded in other studies on oak (Kulfan et al., 1997, 2006; Csoka, 1998; Southwood et al., 2004; Bolz, 2008; Haecker \& Müller, 2008).

There is an evolutionary transition in Mediterranean oaks ranging from evergreen $Q$. ilex and $Q$. coccifera (subgenus Sclerophyllodrys) through the phenologically plastic Q. macrolepis (subgenus Cerris) to the deciduous Q. trojana (subgenus Cerris) (Boratynski et al., 1992; Ne'eman, 1993). This difference is intensified by the fact that deciduous oaks use starch from reserves accumulated in the previous growing season in the biosynthesis of organic matter for new leaves. In evergreen oaks the organic matter comes from recently produced sugars, which are produced by the old but functional leaves (Damesin et al., 1998, and references therein). This is probably a reason for the peaks and the differences in the abundance curves of defoliators. The first peak in May is common to all oaks but in species of the subgenus Sclerophyllodrys it extends into June due to the unfolding of new leaves, which are present along with the old ones. Evidently, the folivorous insects feeding on these species can obtain sugars throughout the growing season and do not show the periodicity in abundance recorded in the other subgenera. Thus, the summer peak in August is absent. In subgenus Cerris it recorded for only one species but in the subgenus Quercus it is prominent (Fig. 1). The autumnal peak is present in all species. The lower level of the summer and autumnal peaks is caused by many factors, the most important being the absence when the leaves are mature of many groups, such as Noctuidae (Alonso \& Herrera, 2000). In fact only seven (eight?) species had a second generation, six in summer and two in autumn. This is in accordance with the results of Cizek et al. (2006), who tested the hypothesis that quantitative defenses restrict the number of generations in European butterflies.

The insects found here perceive differently the three subgenera in the genus Quercus. Fig. 2 indicates the conformity of caterpillar presences with Quercus subgeneric taxonomy with the exception of the planted $Q$. robur pedunculiflora. On the recognition of oak by moths there are at least two not necessarily opposing views. The first comes from the work of Simchuk (2008) who found that certain genotypes of $T$. viridana exhibit marginal fitness (fecundity and body size) on some genotypes of $Q$. petraea and $Q$. pubescens and minimal fitness on other genotypes, and the work of Tovar-Sanchez \& Oyama (2006) who found that the entire arthropod fauna (532 taxa) was determined by the taxonomic status of trees based on a hybridization continuum. The second comes from the work of Tack et al. (2010) who studied the insect herbivore communities on $Q$. robur and found that the only significant factor associated with the structure of the insect community was plant phenology (48\%). Both views are relevant to the current study as the insect assemblage and different oak species have various proximities on Mt Holomontas. For example, in the cluster of subgenus Quercus (Fig. 2) Q. dalechampii is grouped with $Q$. pubescens but not with the taxonomically and geographically similar $Q$. frainetto. Also, Q. macrolepis is grouped closer to $Q$. robur pedunculiflora than to $Q$. trojana, which is taxonomically more similar, mainly because of its spatial proximity. However, Q. macrolepis is included in the subgenus cluster Cerris rather than the cluster with $Q$. pubescens with which it is syntopic.

This study showed that in this assemblage of oak foliage eating insects time is partitioned in a way that minimizes inter-specific interference. The partitioning of the season by the groups of insects that exploit the same 

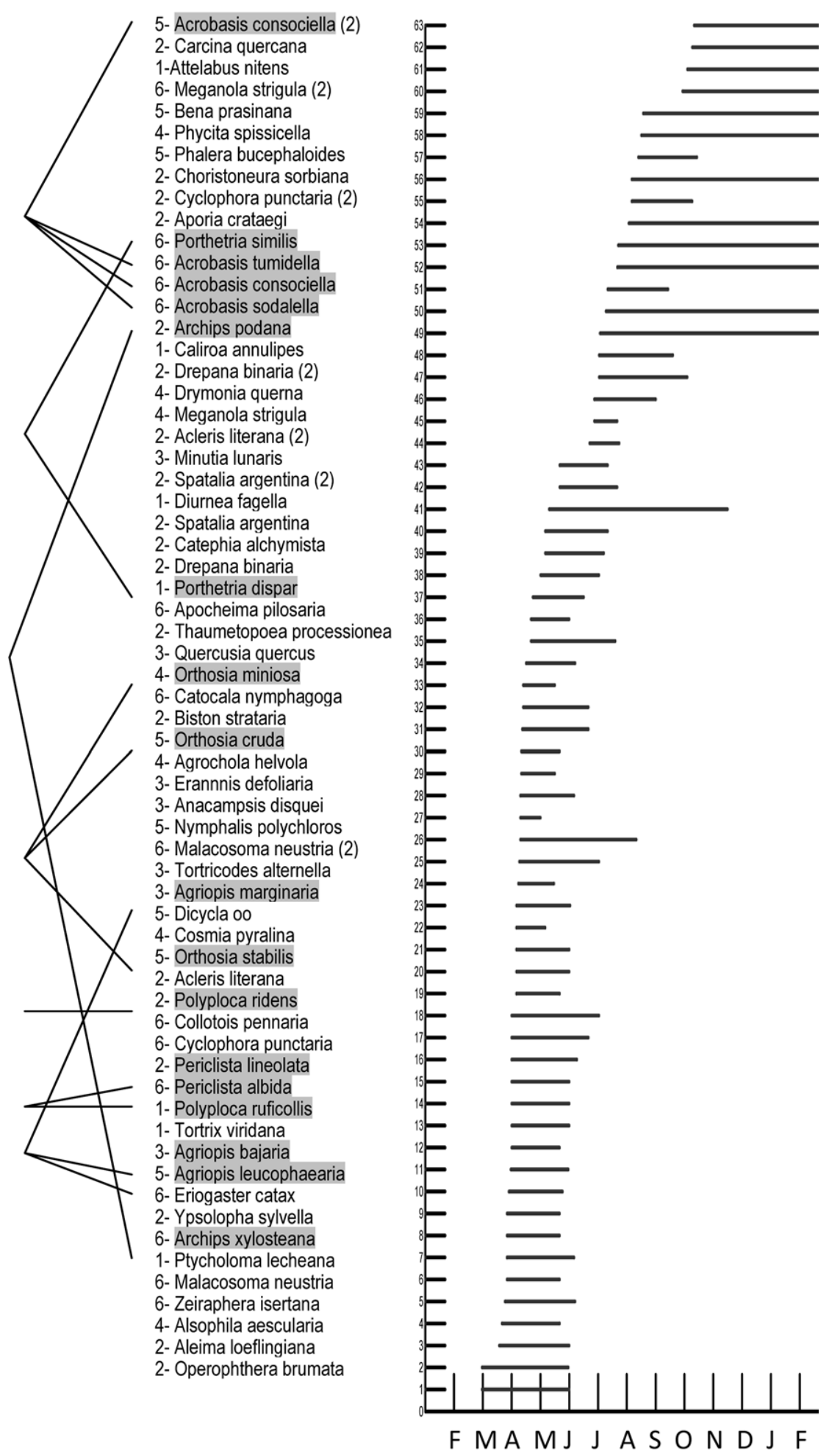

Fig. 4. The larval periods of the insects feeding on the leaves of oaks on Mt Holomontas sorted by means of the months in which their peak numbers were recorded. Only presences are considered here. Insects with two generations are shown as different species followed by the number " 2 ". Insect names are preceded with the affiliated cluster name marked with Arabic numerals (1...6) as shown in Fig. 3. Cilix glaucata is not shown because its larvae were rarely collected. This insect is represented by Periclista albida, for which the start and end date of appearance of its larvae were the same. Congeneric species are shown against a grey background and are linked by converging lines.

species of oak tree is random but non random when they are considered as an assemblage.

The number of specialists $(29 \%)$ is considerably larger than in assemblages of defoliators on oaks in the north.
Bolz (2008) records a small percentage (5\%) of monophagous oak moths while Haecker \& Mueller (2008) records between $12.5 \%$ and $26.1 \%$. The restriction to a narrow time window is in accordance with the "adaptive 
deme formation hypothesis", which states that monophagous short-lived insects on long-lived hosts are locally adapted to them (Edmunds \& Alstad, 1978; Mopper, 2005) although the scale of this adaptation and subsequent formation of adaptive demes is questioned in the case of the pedunculate oak (Quercus robur) / monophagous leaf-mining moth (Tischeria ekebladellla, Lepidoptera: Tischeriidae) system (Roslin et al., 2006, Gripenberg et al., 2007).

The general niche overlap correlates well with feeding specialization and becomes smaller with increase in specialization, that is the proportion of specialists increases and more importantly there are fewer competitors. This supports the idea that specialization within the same guild is a means of escaping competition from conspecifics (Schoener, 1986). The result is a mixture of specializations in insect communities. The existence of generalists (the existing species) and specialists is seen here in the three Agriopis species within this assemblage.

This mixture of feeding specializations and the many species of oaks they can feed on (and other plants) probably resulted in the prevalence of asymmetries in the niche specific overlaps. Asymmetries, especially strong ones, are the rule in insects (Denno et al., 1995) and only some sap-feeders and bark beetles interact symmetrically. However, Denno et al. (1995) found a low percentage of asymmetrical interactions.

Specialization and time partitioning are expected to interact according to the "niche compression hypothesis" (Schoener, 1974b). Since larvae can withstand starvation for some time (Van Asch \& Visser, 2007) they can abandon some food items - i.e. leaves - or the generalists expand their diets to compete with specialists, which as a rule are small insects. For example, in the geometrid genus Agriopis there is one monophagous (m), one oligophagous (o) and one polyphagous (p) species (Table 2). The feeding niche of $A$. leucophaearia overlaps those of nine other insects in the same feeding group. Moreover, this insect is separated from the feeding guild (cluster 5) of the other two congeners (cluster 3) (Fig. 3), principally on the basis of its high abundance on $Q$. frainetto and to a lesser degree on $Q$. dalechampii.

Insect phenology cannot be more closely synchronized with that of their host plants (for Operophtera brumata and Quercus rubra, Topp \& Kirsten, 1991; Tikkanen \& Julkunen-Tiitto, 2003). As a result, the degree of synchrony strongly varies between years (Van Asch \& Visser, 2007). Thus, compared to trophic separation, separation in time is not important and A. leucophaearia coincides with $A$. bajaria, which is in turn quite distant in time from A. marginaria (Fig. 4), which is in cluster 3 (Fig. 3). Interestingly, Haecker \& Mueller (2008), using literature from middle Europe, classify A. leuophaearia and $A$. marginaria as oligophagous on deciduous trees.

Another situation is found in the genus Acrobasis of which the three monophagous (species (Table 2a) occur in the same cluster (6) but in three different sub-clusters (Fig. 3). As seen in Fig. 4 separation in time does not occur and all three species are present in July-August.
However, A. consociella has a second generation, which reduces the packing of these insects in the assemblage. This occurs in a variety of situations where shortening of generation time creates room for an additional generation in the framework of host plant phenology. This is formulated as the "time constrained hypothesis" (Nylin et al., 2009). In terms of voltinism Cizek et al. (2006) predict that European butterflies have fewer generations when their host plants are qualitatively defended, the favourable season (food availability) is short, and they are small in size and gregariousness. Oaks are quantitatively defended and the favourable season on Mt Holomontas is long. Also, the same authors indicate that some insects remain monovoltine despite the fact there is sufficient time for more generations (there are no time constraints), probably because there are phylogenetic constraints. This possibly accounts for the low number (seven out of fifty-eight species, Table $6 \mathrm{~b}$ ) of bivoltine species in the system studied.

In terms of biogeography the widely distributed Holarctic insects partition time better than those of other biogeographic regions because they have crossed more genetic barriers and experienced more competition. Eventually, they become locally extinct or cause the extinction of other species. Perhaps, one reason why widely distributed species do not show clear partitioning of resources is that their local populations are not more phenologically plastic than narrowly distributed species (Altermatt, 2010).

Time-partitioning is achieved by behavioural and physiological mechanisms in periods as short as one day or phenologically if the period is one year. Moreover, the phenology of an insect depends strongly on the completion of certain developmental stages, which is essentially a polygenic trait. Thus, time-partitioning among the members of all insect assemblages are unlikely to be perfect. In the case of at least one host plant, $Q$. macrolepis, this does not hold since individuals of this plant can be either deciduous or evergreen (Ne'eman, 1993). There are many ways to circumvent the phenological variation between host trees. One way is for the insects to track the variation in each oak species by changing their feeding phenology. Another way is for the insects to become more polyphagous and exploit other congeneric plants. Then the large number of insect species and voltinism transform partitioning from random to regular. Random partitioning of time can also result if time is used as a means of reducing competition between species whose niches widely overlap. The co-occurrence of deciduous and evergreen oaks enables insects to escape the constraints of time by feeding on both species at different times of the year.

ACKNOWLEDGEMENTS. We thank A. Feest for critically reading the manuscript and making useful suggestions. Thanks are extended to E. Lahlou for compiling the literature, data entry and typing. Funding for this project came from the Greek Secretariat of Science and Technology.

\section{REFERENCES}

ABER J.D. 1979: A method for estimating foliage-height profiles in broad-leaved forests. J. Ecol. 67: 35-40. 
Alonso C. \& Herrera C.M. 2000: Seasonal variation in leaf characteristics and food selection by larval noctuids on an evergreen Mediterranean shrub. Acta Oecol. 21: 257-265.

Altermatt F. 2010: Tell me what you eat and I'll tell you when you fly: diet can predict phenological changes in response to climate change. Ecol. Lett. 13: 1475-1484.

Bolz R. 2008: Diversity of moth communities (Insecta: Lepidoptera) in differently-structured oak-hornbeam forests: a comparison of different phases of succession in coppice with standards and forests with high standared trees. In Floren A. \& Schmidl J. (eds): Canopy Arthropod Research in Europe: Basic and Applied Studies from the High Frontier. Bioform Entomology, Nürnberg, pp. 427-443.

Boratynski A., Browicz K. \& Sielinski J. 1992: Chorology of Trees and Shrubs in Greece. Polish Academy of Sciences, Poznan / Kórnik, 286 pp.

Chang F., Carey V., Qiu W., Zamar R.H., Lazarus R. \& Wang X. 2010: clues: An R Package for Nonparametric Clustering Based on Local Shrinking. http://cran.at.r-project.org /web/packages/clues/ < accessed 25.xii.2010>.

Cizek L., Fric Z. \& Konvicka M. 2006: Host plant defences and voltinism in European butterflies. Ecol. Entomol. 31: 337-344.

Coley P.D., Bryant J.P. \& Chapin F.S. III. 1985: Resource Availability and plant anti-herbivore defense. Science 230: 895-899.

CoRnell H.V. 1985: Local and regional richness of Cynipine gall wasps on California oaks. Ecology 66: 1247-1260.

CsokA G. 1998: Oak defoliating insects in Hungary. In McManus M.L. \& Liebhold A.M. (eds): Proceedings: Population Dynamics, Impacts, and Integrated Management of Forest Defoliating Insects. USDA Forest Service General Technical Report NE-247, pp. 334-355.

Damesin C., Rambal S. \& Joffre R. 1998: Seasonal and annual changes in leaf $\delta 13 \mathrm{C}$ in two co-occurring Mediterranean oaks: relations to leaf growth and drought progression. Funct. Ecol. 12: 778-785.

Denno R.F., McClure M.S. \& Ott J.R. 1995: Interspecific interactions in phytophagous insects: Competition reexamined and resurrected. Annu. Rev. Entomol. 40: 297-331.

Edmunds G.F. \& Alstad D.N. 1978: Coevolution in insect herbivores and conifers. Science 199: 941-945.

FATTORINI S. 2005: A simple method to fit geometric series and broken stick models in community ecology and island biogeography. Acta Oecol. 28: 199-205.

FEENY P. 1970: Seasonal changes in oak leaf tannins and nutrients as a cause of spring feeding by winter moth caterpillars. Ecology 51: 565-581.

FÜHRER E. 1998: Oak decline in central Europe: a synopsis of hypotheses. In McManus M.L. \& Liebhlold A.M. (eds): Proceedings: Population Dynamics, Impacts, and Integrated Management of Forest Defoliating Insects. USDA Forest Service General Technical Report NE-247, pp. 7-24.

Gaus R. 1982: Familienreihe Cynipoidea. In Schwenke W. (ed.): Die Forstschändlinge Europas, Vol. 4. Paul Parey Verlag, Hamburg, pp. 234-255.

Giller P.S. 1984: Community Structure and the Niche. Chapman and Hall, London, $176 \mathrm{pp}$.

Gripenberg S., Morrien E., Cudmore A., Salminen J.-P. \& RosLIN T. 2007: Resource selection by female moths in a heterogeneous environment: what is a poor girl to do? J. Anim. Ecol. 76: 854-865.

HACKeR H. \& MÜLleR J. 2008: Startification of "macroLepidoptera" (Insecta) in northern Bavarian forest stands dominated by different tree species. In Floren A. \& Schmidl J (eds): Canopy Arthropd Research in Europe: Basic and
Applied Studies from the High Frontier. Bioform, Nürnberg, pp. 355-382.

Hammer O. \& Harper D. 2006: Introduction to Paleontological Data Analysis. Blackwell, Oxford, 351 pp.

Harris J.W.E., Collis D.G. \& Magar K.M. 1972: Evaluation of the tree-beating method for sampling defoliating forest insects. Can. Entomol. 104: 723-729.

JoLIVET P. 1998: Interrelationships between Insects and Plants. CRC Press, Boca Raton, FL, 336 pp.

Josifov M. 1986: Verzeichnis der von den Balkanhalbilsen bekannten Heteropterenarten. Faun. Abh. Mus. Tierk. (Dresden) 14: 61-93.

KaILIDIS D.S. 1986: Forest Entomology. Giapouli-Giahoudi, Thessaloniki, 397 pp. [in Greek].

KARBAN R. 1985: Addition of periodical cicada nymphs to an oak forest: effects on cicada density, acorn production and rootlet density. J. Kans. Entomol. Soc. 58: 269-276.

Kulfan M., Septak L. \& Degma P. 1997: Lepidoptera larvae communities on oaks in SW Slovakia. Biologia (Bratislava) 52: $247-252$.

Kulfan M., Holecova M. \& FalciK J. 2006: Caterpillar (Lepidoptera) communities on European Turkey oak (Quercus cerris) in Malé Karpaty Mts (SW Slovakia). Biologia (Bratislava) 61: 573-578.

LOREAU M. 1992: Time scale of resource dynamics and coexistence through time partitioning. Theor. Popul. Biol. 41: 401-412.

MAAREL VAN DER E. 1979: Transformation of cover abundance values in phytosociology and its effects on community similarity. Vegetatio 39: 97-114.

Marquis R.J. \& Phelan C.J. 1994: Insectivorous birds increase growth of white oak through consumption of leaf-chewing insects. Ecology 75: 2007-2014.

McCune B., Grace J.B. \& Urban D.L. 2002: Analysis of Ecological Communities. MjM, Gleneden Beach, OR, 300 pp.

MOPPER S. 2005: Phenology - how time creates spatial structure in endophagous insect populations. Ann. Zool. Fenn. 42: 327-333.

NE'EMAN G. 1993: Variations in leaf phenology and habit in Querqus ithaburensis, a Mediterranean deciduous tree. $J$. Ecol. 81: 627-634.

Niemelä P. \& Haukioja E. 1982: Seasonal patterns in species richness of herbivores: macrolepidopteran larvae on Finnish deciduous trees. Ecol. Entomol. 7: 169-175.

Nylin S., Nygren G.H., Soederlind L. \& Stefanescu C. 2009: Geographical variation in host plant utilization in the comma butterfly: the roles of time constraints and plant phenology. Evol. Ecol. 23: 807-825.

Oksanen J., Kindt R., Legendre P., O’Hara R.B., Simpson G.L., Stevens M.H.H. \& Wagner H. 2008: vegan: Community Ecology Package. $R$ Package Version 1.13-2. http://vegan. r-forge.r-project.org/ <accessed 17.v.2008>.

ORLOCI L. 1979: Non-linear data structures and their description. In Orloci L., Rao C.R. \& Stiteler W.M. (eds): Multivariate Methods in Ecological Work. ICPH, Burtonsville, MD, pp. 191-202.

OzanNe C.M.P. 2005: Techniques and methods for sampling canopy insects. In Leather S. (ed.): Insect Sampling in Forest Ecosystems. Blackwell, Oxford, pp. 146-167.

Patocka J. 1980: Die Raupen und Puppen der Eichenschmetterlinge Mitteleuropas. Paul Parey Verlag, Germany, 188 pp.

Petraitis P.S. 1979: Likelihood measures of niche breadth and overlap. Ecology 66: 1983-1985.

Petrattis P.S. 1985: The relationship between likelihood niche measures and replicated tests for goodness of fit. Ecology 66: 1983-1985. 
Poole R.W. \& Rathcke B.J. 1979: Regularity, randomness and aggregation in flowering phonologies. Science 203: 470-471.

R Development Core Team 2010: $R$ : A language and Environment for Statistical Computing. R Foundation for Statistical Computing, Vienna.

Rabinowitz D., Rapp J.K., Sork V.L., Rathcke B.J., Reese G.A. \& Weaver J.C. 1981: Phenological properties of wind- and insect pollinated prairie plants. Ecology 62: 49-56.

RathCKe B.J. 1984: Patterns of flowering phenologies: Testability and causal inference using a random model. In Strong D.R., Simberloff D., Abele L.G. \&. Thistle A.B. (eds): Ecological Communities: Conceptual Issues and the Evidence. Princeton University Press, Princeton, NJ, pp. 383-393.

Roslin T., Gripenberg S., Salminen J.-P., Karonen M., O’Hara R.B., Pihlaja K. \& Pulkkinen P. 2006: Seeing the trees for the leaves / oaks as mosaics for a host-specific moth. Oikos 113: $106-120$.

SCHOENER T.W. 1974a: Resource partitioning in ecological communities. Science 185: 27-39.

SCHOENER T.W. 1974b: The compression hypothesis and temporal resource partitioning. Proc. Nat. Acad. Sci. 71: $4169-4172$

SCHoEner T.W. 1986: Resource partitioning. In Kikkawa J. \& Anderson D.J. (eds): Community Ecology: Pattern and Process. Blackwell, London, pp. 91-126.

Schwenke W. (ed.) 1978: Die Forstschädlinge Europas: Schmetterlinge Vol. 3. Paul Parey Verlag, Hamburg, 467 pp.

Siмсник A.P. 2008: Influence of genetic variation of oak trees as a nutrient substrate adaption of the pea green oak leafroller. Cytol. Genet. 42: 45-52.

Southwood T.R.E. \& Kennedy C.E.J. 1983: Trees as islands. Oikos 41: 359-371.
Southwood T.R.E., Wint G.R.W., Kennedy C.E.J. \& GreenwooD S.R. 2004: Seasonality, abundance, species richness and specificity of the phytophagous guild of insects on oak (Quercus) canopies. Eur. J. Entomol. 101: 43-50.

Southwood T.R.E., Wint G.R.W., KenNedy C.E.J. \& GreenwooD S.R. 2005: The composition of the arthropod fauna of the canopies of some species of oak (Quercus). Eur. J. Entomol. 102: 65-72.

Tack A.J.M., Ovaskainen O., Pulkkinen P. \& Roslin T. 2010: Spatial location dominates over host plant genotype in structuring an herbivore community. Ecology 91: 2660-2672.

TikKanen O.-P. \& Julkunen-TittTo R. 2003: Phenological variation as protection against defoliating insects: the case of Quercus robur and Operophthera brumata. Oecologia 136: 244-251.

TOPP W. \& KirSTEN K. 1991: Synchronisation of preimaginal development and reproductive success in the winter moth, Operophthera brumata L. J. Appl. Entomol. 111: 137-146.

Tovar-Sanchez E. \& Oyama K. 2006: Community structure of canopy arthropods associated to Quercus crassifolia X Quercus crassipes complex. Oikos 112: 370-381.

VAN Asch M. \& VISSER M.E. 2007: Phenology of forest caterpillars and their host trees: the importance of synchrony. Annu. Rev. Entomol. 52: 37-55.

WILKINSON L. 2007: SYSTAT 12. Systat Software Inc., Evanston, IL.

Yela J.L. \& Herrera C.M. 1993: Seasonality and life cycles of woody plant-feeding noctuid moths (Lepidoptera: Noctuidae) in Mediterranean habitats. Ecol. Entomol. 18: 259-269.

Received January 21, 2011; revised and accepted September 1, 2011

APPENDIX S1. Additional references used in this study for the identification of insects and determination of their zoogeographical and host ranges.

Anonymous 1992: Results of the First National Forest Inventory. Hellenic Ministry of Agriculture, Athens, 134 pp.

Donevski C. 1984: Entomofauna (Lepidoptera) of oak (Quercus coccifera) in SR Macedonia. Fragm. Balcan. Mus. Macedon. Sci.

Natur. 12: 63-70.

EsCHerich K. 1931: Die Forstinsekten Mitteleuropas. Paul Parey, Berlin, 825 pp.

Ivashof A.V. \& Suslova G.N. 1990: The overwindering population of Trichogramma telengai, an egg parasite of the oak roller Tortrix viridana in the oak forests of the Crimea. Izvest. Vyssh. Uchebn. Zaved. (Lesnoy Zh.) 5: 9-13.

KaILIDIS D.S. 1981: The Insects of Oak in Greece. Scientific Annals 24, Aristotle University of Thessaloniki, pp. 129-139.

Kailidis D.S. \& Georgevits R. 1974: The Forest Insects of Greece. Scientific Annals 16, Aristotle University of Thessaloniki, School of Agriculture and Forestry, pp. 233-271.

Kunnt P. 1911: Illustriete Bestimmungs-Tabellen der Käfer Deutschlands. E. Schweizerbart'sche Verlag, Stuttgart, 1138 pp.

LERAUT P. 2006: Moths of Europe. NAP Editions, France, 396 pp.

Meyrick E. 1968: A Revised Handbook of British Lepidoptera. E.W. Classey, Hampton, 915 pp.

Patocka J. 1980: Raupen und Puppen der Eichenshmetterlinge Mitteleuropas. Paul Parey, Hamburg, Berlin, 188 pp.

Schoerogge K. 1991: Zur biologie der Eichenblattwespen Caliroa cinxia Klug. und Caliroa annulipes Klug. (Hymenoptera, Tenthredinidae) und deren Larvalparasitoiden. J. Appl. Emtomol. 111: 365-379.

SwarscheK B. 1958: Die Larvalsystematik der Wickler (Tortricidae und Carposidae). Academie Verlag, Berlin, 269 pp.

Zlatanov S. 1971: Insektenschädlinge der Eiche in Bulgarien. Akademie der Landwirtschaftswissenschaften in Bulgarien, Sofia, $212 \mathrm{pp}$. 
TABLE S2. Numbers of larvae of all the species of insects collected from eight species of Quercus during this study. In the lower panel are listed all the species of insect recorded in the study plots on Mt. Cholomontas. The specialization status was based on records in the literature (e.g. Schwenke, 1978) and personal observations.

\begin{tabular}{|c|c|c|c|c|c|c|c|c|}
\hline Insect species & frainetto & dalechampii & pubescens & ilex & coccifera & macrolepis & pedunculiflora & trojana \\
\hline Polyploca ruficollis & 181 & 255 & 74 & 0 & 0 & 0 & 0 & 0 \\
\hline Polyploca ridens & 0 & 0 & 578 & 0 & 0 & 0 & 0 & 0 \\
\hline Drepana binaria & 273 & 0 & 0 & 0 & 0 & 0 & 0 & 0 \\
\hline Cilix glaucata & 2 & 2 & 3 & 0 & 0 & 0 & 0 & 0 \\
\hline Anacampsis disquei & 287 & 187 & 262 & 0 & 0 & 312 & 0 & 200 \\
\hline Operophthera brumata & 660 & 963 & 578 & 0 & 0 & 55 & 0 & 28 \\
\hline Alsophila aescularia & 102 & 83 & 46 & 0 & 0 & 0 & 0 & 46 \\
\hline Agriopis leucophearia & 311 & 46 & 0 & 0 & 0 & 0 & 0 & 0 \\
\hline Agriopis bajaria & 481 & 0 & 0 & 0 & 0 & 0 & 0 & 0 \\
\hline Agriopis marginaria & 141 & 192 & 115 & 0 & 0 & 0 & 2 & 0 \\
\hline Erannis defoliaria & 891 & 0 & 431 & 0 & 0 & 0 & 201 & 488 \\
\hline Biston strataria & 882 & 0 & 0 & 0 & 0 & 0 & 882 & 0 \\
\hline Collotois pennaria & 0 & 0 & 0 & 0 & 384 & 0 & 0 & 22 \\
\hline Cyclophora punctaria & 303 & 0 & 126 & 152 & 0 & 118 & 143 & 0 \\
\hline Apocheima pilosaria & 31 & 26 & 21 & 0 & 0 & 7 & 10 & 5 \\
\hline Malacosoma neustria & 227 & 303 & 76 & 227 & 341 & 95 & 76 & 171 \\
\hline Eriogaster catax & 281 & 0 & 0 & 0 & 0 & 0 & 0 & 0 \\
\hline Quercusia quercus & 51 & 26 & 13 & 4 & 0 & 21 & 21 & 21 \\
\hline Porthetria dispar & 1,213 & 791 & 105 & 53 & 105 & 527 & 527 & 580 \\
\hline Porthesia similis & 72 & 55 & 21 & 8 & 8 & 29 & 34 & 21 \\
\hline Bena prasinana & 39 & 18 & 21 & 14 & 18 & 32 & 39 & 21 \\
\hline Orthosia cruda & 89 & 69 & 34 & 27 & 27 & 48 & 41 & 48 \\
\hline Orthosia stabilis & 38 & 27 & 24 & 24 & 14 & 31 & 17 & 24 \\
\hline Orthosia miniosa & 414 & 300 & 114 & 29 & 43 & 157 & 128 & 243 \\
\hline Cosmia pyralina & 46 & 39 & 23 & 0 & 0 & 8 & 14 & 8 \\
\hline Dicycla oo & 224 & 25 & 5 & 0 & 0 & 0 & 0 & 0 \\
\hline Agrochloa helvola & 132 & 41 & 5 & 0 & 0 & 0 & 0 & 0 \\
\hline Minutia lunaris & 62 & 25 & 37 & 261 & 670 & 0 & 0 & 0 \\
\hline Catocala nymphagoga & 189 & 59 & 100 & 0 & 0 & 7 & 15 & 0 \\
\hline Catephia alchymista & 58 & 28 & 48 & 0 & 0 & 35 & 32 & 30 \\
\hline Meganola strigula & 74 & 6 & 6 & 0 & 0 & 0 & 0 & 0 \\
\hline Phalera bucephaloides & 620 & 548 & 644 & 0 & 0 & 95 & 262 & 0 \\
\hline Spatalia argentina & 193 & 147 & 129 & 37 & 101 & 83 & 83 & 129 \\
\hline Drymonia querna & 37 & 32 & 35 & 7 & 20 & 17 & 27 & 45 \\
\hline Nymphalis polychloros & 49 & 0 & 0 & 0 & 0 & 0 & 0 & 0 \\
\hline Carcina quercana & 13 & 7 & 7 & 2 & 2 & 7 & 10 & 4 \\
\hline Diurnea fagella & 23 & 23 & 19 & 0 & 0 & 34 & 40 & 25 \\
\hline Aporia crataegi & 105 & 57 & 17 & 0 & 0 & 27 & 34 & 0 \\
\hline Pachytelia villosella & 66 & 71 & 49 & 11 & 11 & 5 & 22 & 5 \\
\hline Acrobasis tumidella & 51 & 38 & 27 & 0 & 0 & 33 & 20 & 13 \\
\hline Acrobasis consociella & 64 & 57 & 30 & 0 & 0 & 47 & 37 & 12 \\
\hline Acrobasis sodalella & 27 & 18 & 15 & 0 & 0 & 18 & 21 & 9 \\
\hline Phycita spissicella & 83 & 67 & 71 & 20 & 28 & 44 & 56 & 28 \\
\hline Thaumetopoea processionea & 21 & 15 & 14 & 0 & 0 & 14 & 17 & 11 \\
\hline Tortricodes alternella & 64 & 51 & 68 & 0 & 0 & 51 & 72 & 47 \\
\hline Tortrix viridana & 35 & 29 & 48 & 0 & 0 & 42 & 48 & 39 \\
\hline Choristoneura sorbiana & 360 & 103 & 60 & 0 & 0 & 43 & 60 & 26 \\
\hline Ptycholoma lecheana & 58 & 42 & 19 & 0 & 0 & 33 & 42 & 25 \\
\hline Zeiraphera isertana & 23 & 25 & 22 & 0 & 0 & 23 & 25 & 20 \\
\hline Archips xylosteana & 302 & 216 & 187 & 0 & 0 & 115 & 245 & 72 \\
\hline Archips podana & 319 & 181 & 181 & 0 & 0 & 0 & 181 & 0 \\
\hline Acleris literana & 282 & 94 & 79 & 0 & 0 & 65 & 152 & 51 \\
\hline Aleima loeflingiana & 239 & 66 & 56 & 0 & 0 & 25 & 97 & 25 \\
\hline Ypsolopha sylvella & 266 & 84 & 266 & 0 & 0 & 23 & 106 & 15 \\
\hline Attelabus nitens & 131 & 14 & 58 & 0 & 0 & 0 & 36 & 0 \\
\hline Caliroa annulipes & 54 & 10 & 10 & 0 & 0 & 5 & 10 & 5 \\
\hline Periclista lineolata & 73 & 63 & 56 & 0 & 0 & 49 & 66 & 42 \\
\hline Periclista albida & 54 & 39 & 36 & 0 & 0 & 36 & 52 & 41 \\
\hline Acrobasis consociella (2) & 27 & 24 & 12 & 0 & 0 & 20 & 15 & 5 \\
\hline Cyclophora punctaria (2) & 185 & 0 & 232 & 139 & 111 & 102 & 158 & 0 \\
\hline Meganola strigula (2) & 62 & 33 & 49 & 0 & 0 & 5 & 26 & 0 \\
\hline
\end{tabular}




\begin{tabular}{|c|c|c|c|c|}
\hline Family & sn & Species & Feeding specialization & Zoogeographical category \\
\hline \multicolumn{5}{|c|}{ LEPIDOPTERA } \\
\hline \multirow{2}{*}{ Cymatophoridae } & 1 & Polyploca ruficollis Fabricius, 1787 & $\mathrm{~m}$ & ES \\
\hline & 2 & P. ridens Fabricius, 1787 & $\mathrm{~m}$ & Med \\
\hline \multirow[t]{2}{*}{ Drepanidae } & 3 & Drepana binaria Hufnagel, 1767 & o & Med \\
\hline & 4 & Cilix glaucata (Scopoli, 1763) & $\mathrm{p}$ & Med \\
\hline Gelechiidae & 5 & Anacampsis disquei Mess, 1907 & $\mathrm{~m}$ & Med \\
\hline \multirow{10}{*}{ Geometridae } & 6 & Operophthera brumata Linnaeus, 1758 & $\mathrm{p}$ & Pal \\
\hline & 7 & Alsophila aescularia Denis et Schiffermüller, 1775 & $\mathrm{p}$ & Pal \\
\hline & 8 & Agriopis leucophaearia Denis et Schiffermüller, 1775 & $\mathrm{~m}$ & Pal \\
\hline & 9 & A. bajaria Denis et Schiffermuller, 1775 & o & ES \\
\hline & 10 & A. marginaria Fabricius, 1777 & $\mathrm{p}$ & Med \\
\hline & 11 & Erannis defoliaria Clerck, 1959 & $\mathrm{p}$ & Pal \\
\hline & 12 & Biston strataria Hufnagel, 1767 & $\mathrm{p}$ & Med \\
\hline & 13 & Collotois pennaria Linnaeus, 1761 & o & ES \\
\hline & 14 & Cyclophora punctaria Linnaeus, 1758 & o & ES \\
\hline & 15 & Apocheima pilosaria Denis et Schiffermüller, 1775 & o & $\mathrm{ES}$ \\
\hline \multirow[t]{2}{*}{ Lasiocampidae } & 16 & Malacosoma neustria Linnaeus, 1758 & $\mathrm{p}$ & Pal \\
\hline & 17 & Eriogaster catax Linnaeus, 1758 & o & $\mathrm{ES}$ \\
\hline Lycaenidae & 18 & Quercusia quercus Linnaeus, 1758 & o & Pal \\
\hline \multirow[t]{2}{*}{ Lymantriidae } & 19 & Porthetria dispar Linnaeus, 1758 & $\mathrm{p}$ & Pal \\
\hline & 20 & Porthesia similis Fuessly, 1775 & $\mathrm{p}$ & Pal \\
\hline \multirow[t]{10}{*}{ Noctuidae } & 21 & Bena prasinana Linnaeus, 1758 & o & Pal \\
\hline & 22 & Orthosia cruda Denis et Schiffermüller, 1775 & o & ES \\
\hline & 23 & O. stabilis Denis et Schiffermüller, 1775 & o & Pal \\
\hline & 24 & O. miniosa Denis et Schiffermüller, 1775 & $\mathrm{p}$ & Med \\
\hline & 25 & Cosmia pyralina Denis et Schiffermüller, 1775 & o & Pal \\
\hline & 26 & Dicycla oo (Linnaeus, 1758) & $\mathrm{m}$ & ES \\
\hline & 27 & Agrochloa helvola Linnaeus, 1758 & $\mathrm{~m}$ & Pal \\
\hline & 28 & Minutia lunaris Denis et Schiffermüller, 1775 & $\mathrm{~m}$ & Med \\
\hline & 29 & Catocala nymphagoga Esper, 1787 & o & Pal \\
\hline & 30 & Catephia alchymista Denis et Schiffermüller, 1775 & o & ES \\
\hline Nolidae & 31 & Meganola strigula Denis et Schiffermüller, 1775 & o & Med \\
\hline \multirow[t]{3}{*}{ Notodontidae } & 32 & Phalera bucephaloides Ochsenheimer, 1810 & $\mathrm{~m}$ & Med \\
\hline & 33 & Spatalia argentina Denis et Schiffermüller, 1775 & o & Med \\
\hline & 34 & Drymonia querna Denis et Schiffermüller, 1775 & o & Pal \\
\hline Nymphalidae & 35 & Nymphalis polychloros (Linnaeus, 1758) & $\mathrm{p}$ & ES \\
\hline \multirow[t]{2}{*}{ Oecophoridae } & 36 & Carcina quercana Fabricius, 1775 & o & Pal \\
\hline & 37 & Diurnea fagella Hubner, 1796 & $\mathrm{p}$ & Pal \\
\hline Pieridae & 38 & Aporia crataegi (Linnaeus, 1758) & o & Med \\
\hline Psychidae & 39 & Pachytelia villosella Ochsenheimer, 1810 & $\mathrm{p}$ & Med \\
\hline \multirow[t]{4}{*}{ Pyralidae } & 40 & Acrobasis tumidella Zincken, 1818 & $\mathrm{~m}$ & Pal \\
\hline & 41 & A. consociella Hubner, 1910-13 & $\mathrm{m}$ & ES \\
\hline & 42 & A. sodalella Zeller, 1848 & $\mathrm{~m}$ & ES \\
\hline & 43 & Phycita spissicella Fabricius, 1776 & o & Pal \\
\hline Thaumetopoeidae & 44 & Thaumetopoea processionea Linnaeus, 1758 & $\mathrm{~m}$ & ES \\
\hline \multirow[t]{9}{*}{ Tortricidae } & 45 & Tortricodes alternella Denis et Schiffermüller, 1775 & o & ES \\
\hline & 46 & Tortrix viridana Linnaeus, 1758 & o & Pal \\
\hline & 47 & Choristoneura sorbiana Hubner, 1799 & o & Pal \\
\hline & 48 & Ptycholoma lecheana Linnaeus, 1758 & $\mathrm{p}$ & ES \\
\hline & 49 & Zeiraphera isertana Fabricius, 1794 & o & Pal \\
\hline & 50 & Archips xylosteana Linnaeus, 1758 & $\mathrm{p}$ & ES \\
\hline & 51 & A. podana Scopoli, 1763 & $\mathrm{p}$ & $\mathrm{ES}$ \\
\hline & 52 & Acleris literana Linnaeus, 1758 & $\mathrm{~m}$ & ES \\
\hline & 53 & Aleima loeflingiana Linnaeus, 1758 & $\mathrm{p}$ & ES \\
\hline Yponomeutidae & 54 & Ypsolopha sylvella Linnaeus, 1758 & $\mathrm{~m}$ & ES \\
\hline \multicolumn{5}{|c|}{ COLEOPTERA } \\
\hline Curculionidae & 55 & Attelabus nitens (Scopoli, 1763) & $\mathrm{p}$ & ES \\
\hline \multicolumn{5}{|c|}{ HYMENOPTERA } \\
\hline \multirow[t]{3}{*}{ Tenthredinidae } & & Caliroa annulipes (Klug, 1816) & o & ES \\
\hline & & Periclista lineolata (Klug, 1816) & $\mathrm{m}$ & ES \\
\hline & 58 & P. albida (Klug, 1816) & $\mathrm{m}$ & ES \\
\hline
\end{tabular}


APPENDIx S3. Explanation and properties of the Poole-Rathcke model.

The Poole-Rathcke model is attractive for several reasons, namely: [1] it can be used to order insect species according to the date of hatching and of the midpoints of the development of the larvae and [2] to test for randomness or regularity among categories or families of insects and the whole assemblage; [3] its predictions are easily statistically testable and permit comparisons with other applications of the method using standard statistical tests (Rabinowitz et al., 1981); [4] it is not limited by evenness or dominance of the species (Fattorini, 2005); [5] the algorithm is easily implemented in a spreadsheet (MS Excel was used for this); [6] it presumes that plant growing period is uniform from year to year; in this study bud burst of all the species of oak occurred from the end February to the beginning of March.

The Poole-Rathcke model was used by Pavon \& Briones (2001) to study the distribution of the peaks of flowering and fruiting of perennial plants in semi-arid scrub. The ability of the model to estimate the expected variances of a time sequence of biological events was exploited by Sanders et al. (2007) who studied the assembly rules of co-occurrences of ground-dwelling ants in a variety of habitats and by Marchinko et al. (2004) who studied character displacement in two barnacle communities in a quest for evidence of inter-specific competition.

In the Poole-Rathcke model (Poole \& Rathcke, 1979) the sample statistic $P$ given below is compared to its expected value $E(P)-$ expected variance of the broken stick model - by means of the ratio $P / E(P)$. That is :

$$
P=\sum_{i=0}^{k}\left(y_{i+1}-y_{i}-[1 /(k+1)]^{2} \cdot[1 /(k+1)]\right)
$$

and its expected value is:

$$
E(P)=\frac{k}{(k+1)^{2} \cdot(k+2)}
$$

where $k$ is the number of insect species, $y_{i}$ and $y_{i+1}$ are the consecutive phenological peaks of species $i$ and $i+1$. Since the abundance curves of larvae on oaks were not of the usual Gaussian type, we were not sure about the location of the peak and in order to calculate $y_{i}$ we used the mid value of the date of the start $(L s)$ and end of larval development $(L e)$ (Rathcke, 1984):

$$
y_{i}=(L s+L e) / 2
$$

The dispersion ratio of $y_{i} \mathrm{~s}$ is given by the formula

$$
\operatorname{Dr}(P)=P / E(P)
$$

the quantity $k \cdot P / E(P)$ is approximately distributed as $\chi^{2}$ with $k$ degrees of freedom. If $\chi_{o b s}^{2}<\chi_{P, k}^{2}$ then the distribution of the larval periods is not significantly different from random at the specified $P$ probability level.

\section{REFERENCES}

Marchinko K.B., NishizAKi M.T. \& Burns K.C. 2004: Community-wide character displacement in barnacles: a new perspective for past observations. Ecol. Lett. 7: 114-120.

Pavon N.P. \& Briones O. 2001: Phenological patterns of nine perennial plants in an intertropical semi-arid Mexican scrub. J. Arid Environ. 49: 265-277.

Sanders N.J., Gotelli N.J., Wittman S.E., Ratchford J.S., Ellison A.M. \& Jules E.S. 2007: Assembly rules of ground-foraging ant assemblages are contingent on disturbance, habitat and spatial scale. J. Biogeogr. 34: 1632-1641.

TABLE S4. Wald-Wolfowitz tests of the larval phenologies (mean of start and end date) of oak foliage feeding insect clusters. An insignificant test $(P>0.05)$ implies that the larval phenologies of the insects belonging to the same cluster are randomly dispersed in time during the season.

\begin{tabular}{ccc}
\hline Cluster of Quercus foliage eating insects & $z$ statistic & Two-tailed $^{1} P$ \\
\hline 1 & -0.293 & $0.769 \mathrm{~ns}^{2}$ \\
2 & -0.466 & $0.642 \mathrm{~ns}$ \\
3 & -1.613 & $0.107 \mathrm{~ns}$ \\
4 & -0.293 & $0.769 \mathrm{~ns}$ \\
5 & 0.604 & $0.546 \mathrm{~ns}$ \\
6 & -1.006 & $0.314 \mathrm{~ns}$ \\
\hline
\end{tabular}

${ }^{1}$ because the absolute value of $z$ is tested; ${ }^{2}$ ns stands for not significant. 